\title{
Analysis of Differential Display RT-PCR Products Using Fluorescent Primers and GENESCAN $^{\mathrm{TM}}$ Software
}

\author{
Kenneth R. Luehrsen, Lily L. Marr, Esther van der Knaap ${ }^{1}$ and Susan Cumberledge ${ }^{2}$ \\ PE Applied Biosystems, Foster City, CA, ${ }^{1}$ Michigan State University, East Lansing, MI, and \\ 2University of Massachusetts, Amherst, MA, USA
}

BioTechniques 22:168-174 (January 1997)

\begin{abstract}
Differential display reverse transcription PCR (DDRT-PCR) is a procedure used to identify the induction or repression of gene expression. In most DDRT-PCR protocols, radioisotopes are incorporated during $P C R$ and the $C D N A$ products are detected by autoradiography. This report describes the fluorescent labeling of $c D N A s$ and their detection on automated sequencers from PE Applied Biosystems. A fluorescent tag can be incorporated into the PCR product by using either a labeled primer or a labeled dUTP. The fluorescent signals are analyzed by GENESCAN ${ }^{\mathrm{TM}}$ software. Fluorescent DDRT$P C R$ increases throughput and obviates the handling of hazardous radioisotopes. A PCR cycling profile, expected to give improved reproducibility, is also described. Because amplified cDNAs can't be recovered from the automated sequencer gel, suggestions are given for the identification and recovery of differentially expressed cDNAs.
\end{abstract}

\section{INTRODUCTION}

Many studies attempt to correlate a novel phenotype with changes in gene expression. The most widely used approach to gene discovery is the construction and screening of subtractive cDNA libraries. Standard cDNA libraries suffer from several drawbacks that include the requirement for substantial quantities ( $\geq 1 \mathrm{mg}$ ) of cellular RNA, passage through $E$. coli and labor-intensive identification of clones. Recently, methods of cDNA library construction based on reverse transcription-polymerase chain reaction (RT-PCR) have been reported. These new methods include representational difference analy- sis (RDA) of cDNA (4), serial analysis of gene expression (SAGE) (15), arbitrarily primed PCR (AP-PCR) (11) and differential display RT-PCR (DDRT-PCR) (7). DDRT-PCR has been used to identify and clone genes involved in neoplasias, senescence and development $(1,3,6,9)$.

In the initial step of DDRT-PCR, first-strand cDNA is synthesized using a poly $(\mathrm{dT})$ primer that has one or more selective nucleotides at its $3^{\prime}$ end (see Figures 1 and 2). Aliquots of the synthesized cDNA are amplified in several PCRs, each with a different upstream, arbitrary primer. For the standard DDRT-PCR, a radiolabeled (33P-, $32 \mathrm{P}$ - or ${ }^{35} \mathrm{~S}-$ ) nucleotide or primer is incorporated into the amplified cDNA and detected by autoradiography.

We developed an alternative protocol in which fluorescent labels are used for detection. There are several advantages of fluorescent vs. isotope detection: These include safety, longterm storage of completed reactions, the lower cost of reagents and their disposal, and higher throughput by multiplexing PCRs that contain different-color fluorophores. Two protocols describing fluorescent detection of DDRT-PCR products have been reported $(2,5)$. Here we present an optimized DDRT-PCR protocol using primers labeled with either the fluorescein derivatives JOE or FAM or the rhodamine derivative TAMRA. A DDRT-PCR protocol in which fluorescent dUTPs are used to uniformly label the cDNAs is also reported. The reactions can be run on the Applied Biosystems PRISM $^{\mathrm{TM}}$ DNA Analysis Systems Models 373 or 377, or the Genetic Analyzer Model 310 (PE Applied Biosystems, Foster City, CA, USA). The display is analyzed with GENESCAN ${ }^{\mathrm{TM}}$ software (PE Applied Biosystems). We also suggest an im- 


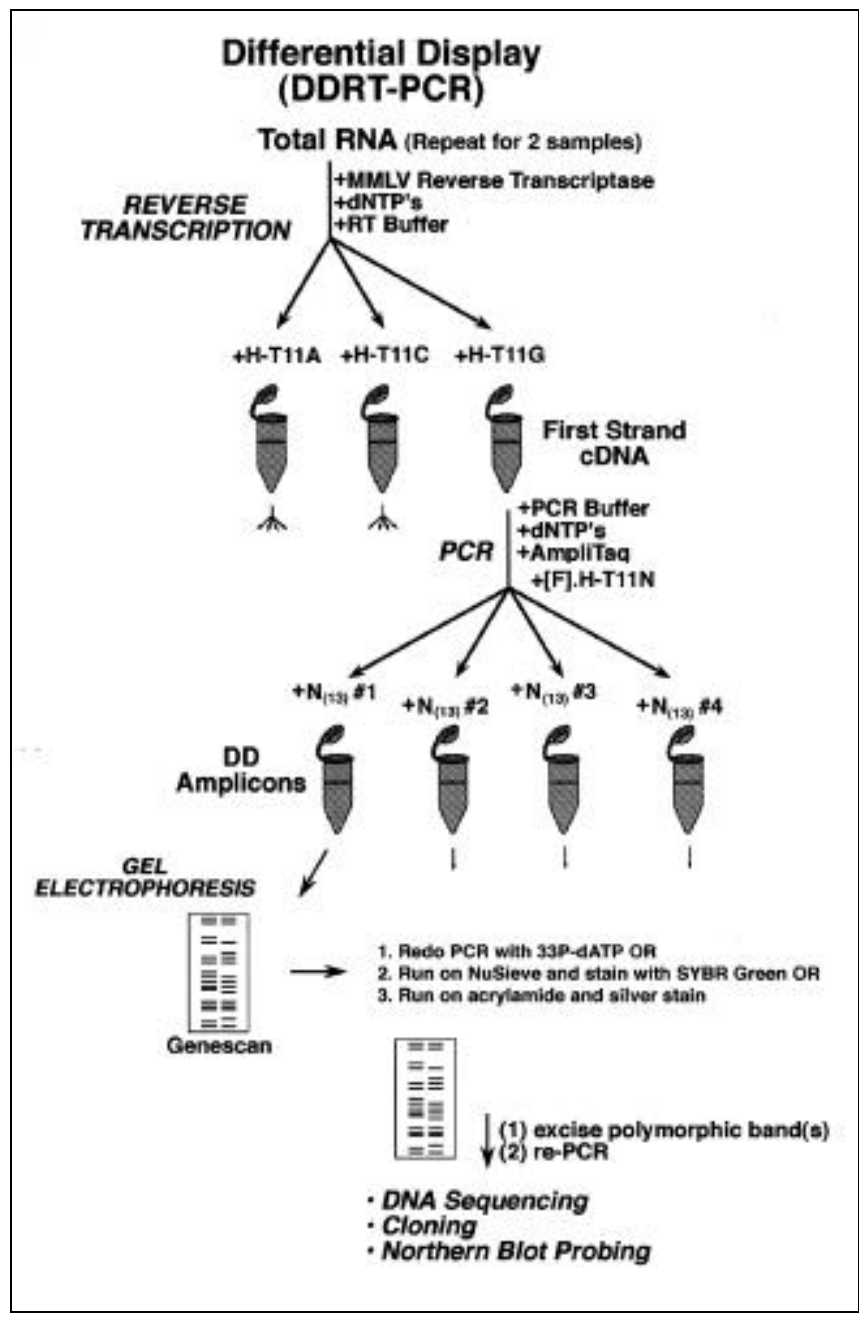

Figure 1. Overview of fluorescent DDRT-PCR.

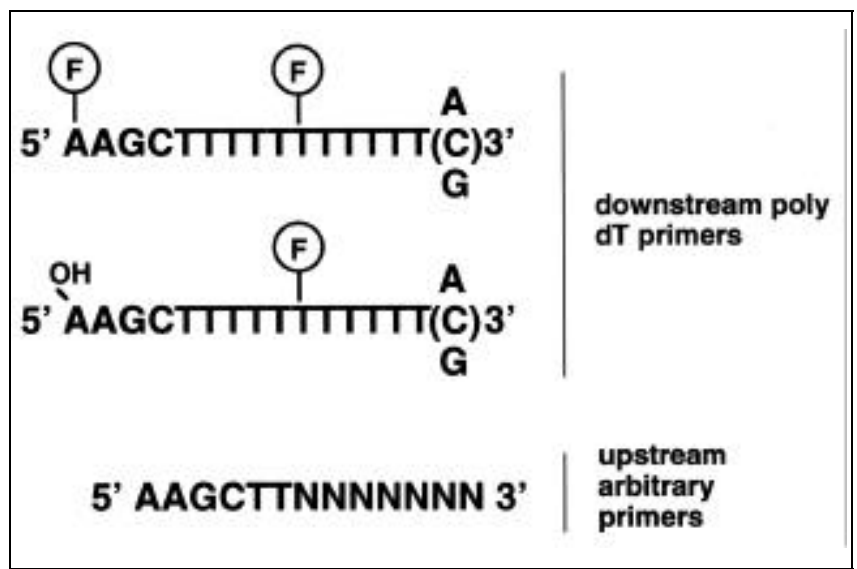

Figure 2. Fluorescent primer design. Each of the three poly(dT) primers has a HindIII site at its $5^{\prime}$ end and a different selective nucleotide at its $3^{\prime}$ end (8). Each oligomer can be synthesized by incorporating a fluorescent phosphoramidite at the $5^{\prime}$ end. In addition, or alternatively, a linker-arm $\mathrm{T}$ can be incorporated at position 10 , and the fluorescent label can be added to the linker by a post-synthesis condensation reaction. By using an internal fluorescent label, a ${ }^{33} \mathrm{P}$ or ${ }^{35} \mathrm{~S}$ radiolabel can be added by polynucleotide kinase, if desired, allowing for both radioactive and fluorescent analysis. TAMRA, JOE or FAM was added to the poly(dT) primers ending in A (TAMRA. H-T11A), C (JOE.H-T11C) or G (FAM.HT11G), respectively. The choice of fluorescent label for each poly(dT) primer sequence was arbitrary; other combinations of primer and fluorescent label also work well (not shown). proved cycling profile and procedures for the recovery of differentially expressed cDNAs.

\section{MATERIALS AND METHODS}

Most of the primers used in this study were obtained from GenHunter (Memphis, TN, USA). The buffers, dNTPs, Moloney murine leukemia virus (M-MLV) reverse transcriptase and AmpliTaq ${ }^{\circledR}$ DNA Polymerase needed for the reactions are included in the GeneAmp ${ }^{\circledR}$ RNA PCR Kit from Perkin-Elmer (Norwalk, CT, USA). Fluorescent dUTPs were obtained from PE Applied Biosystems. Primers labeled with fluorescent tags were prepared at PE Applied Biosystems. TRI Reagent ${ }^{\circledR}$ was obtained from Molecular Research Center (Cincinnati, OH, USA). ${ }^{33} \mathrm{P}-\mathrm{dATP}$ was obtained from NEN Life Sciences Products (Boston, MA, USA). Autoradiography was done using Kodak MR-1 film (Eastman Kodak, Rochester, NY, USA). NuSieve ${ }^{\mathrm{TM}}$ GTG agarose and the DNA stain SYBR ${ }^{\circledR}$ Green were obtained from FMC BioProducts (Rockland, ME, USA). RNase-free DNase was RQ1 from Promega (Madison, WI, USA). The 1-kb ladder DNA marker was purchased from Life Technologies (Gaithersburg, MD, USA). $1 \times$ TBE buffer is $100 \mathrm{mM}$ Tris- $\mathrm{HCl}, \mathrm{pH} 8.3,90 \mathrm{mM}$ borate, $1 \mathrm{mM}$ EDTA.

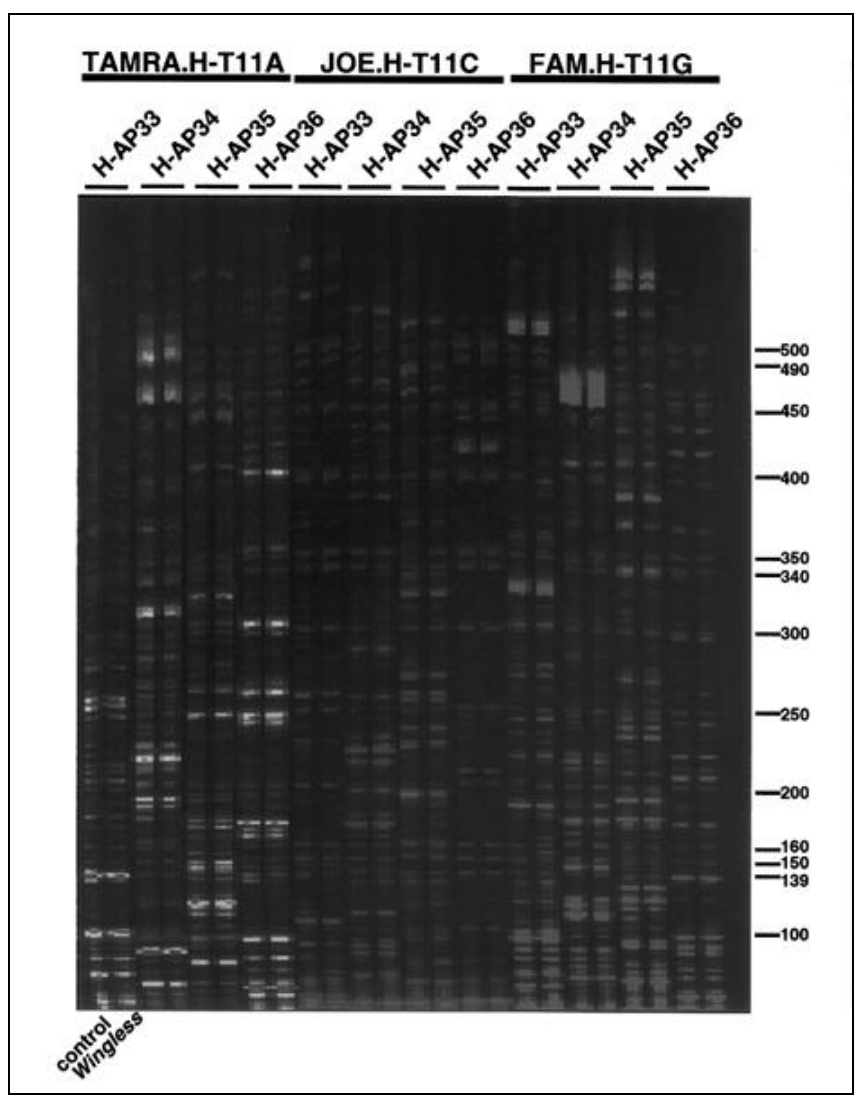

Figure 3. Gel view of data using GENESCAN software. DDRT-PCRs for D. melanogaster pMK33 (control; alternating lanes) and pMK33-3 (Wingless; alternating lanes) cell line RNAs were done using the three indicated poly $(\mathrm{dT})$ primers (labeled at the $5^{\prime}$ end) and four arbitrary primers (H-AP33 to 36). A similar profile was obtained using poly(dT) primers containing an internal fluorescent label. After electrophoresis, the gel image was reconstructed by the GENESCAN software. The TAMRA, JOE and FAM dyes appear yellow, green and blue, respectively. The GENESCAN-500 ROX size standards are in red; the length (in nucleotides) of each standard is shown to the right of the gel. 


\section{RNA Preparation}

Drosophila melanogaster RNA was derived from two cell lines: one was transformed with vector DNA (pMK33; control), and the other was transformed with an expression cassette containing the Wingless gene (pMK33-3). Total RNA was purified with TRI Reagent according to the manufacturer's instructions. Rice RNA from gibberellin (GA)-induced and control plants was prepared as described (14). To destroy any contaminating DNA, the RNA preparations were treated with $1 \mu \mathrm{g} / \mathrm{mL}$ RNase-free DNase for $30 \mathrm{~min}$, followed by phenol/chloroform extraction and ethanol precipitation.

\section{DDRT-PCR}

Purified total RNA was transcribed into cDNA in a $20-\mu \mathrm{L}$ reaction by mixing $2 \mu \mathrm{L} 10 \times$ PCR Buffer II ( $100 \mathrm{mM}$ Tris$\mathrm{HCl} \mathrm{pH} 8.3,500 \mathrm{mM} \mathrm{KCl}), 4 \mu \mathrm{L} 25 \mathrm{mM} \mathrm{MgCl}_{2}$, a $1.6-\mu \mathrm{L}$ mixture of dNTPs (each at $1.25 \mathrm{mM}$ ), $2 \mu \mathrm{L} 2 \mu \mathrm{M}$ poly(dT) primer (unlabeled), $2 \mu \mathrm{L}$ total RNA at $100 \mathrm{ng} / \mu \mathrm{L}, 7.4 \mu \mathrm{L}$ RNase-free water and $1 \mu \mathrm{L}$ M-MLV reverse transcriptase at $50 \mathrm{U} / \mu \mathrm{L}$. The reaction was incubated in a GeneAmp PCR System 2400 (or equivalent) for $20 \mathrm{~min}$ at $42^{\circ} \mathrm{C}$, followed by 5 min at $75^{\circ} \mathrm{C}$ and a $4^{\circ} \mathrm{C}$ hold.

When incorporating a fluorescent primer, a $20-\mu \mathrm{L}$ PCR was assembled with the following components: $2 \mu \mathrm{L} 10 \times$ PCR Buffer II, $2 \mu \mathrm{L} 25 \mathrm{mM} \mathrm{MgCl} 2,1.6-\mu \mathrm{L}$ mixture of dNTPs (each at $1.25 \mathrm{mM}$ ), $2 \mu \mathrm{L} 2 \mu \mathrm{M}$ arbitrary sequence primer, $2 \mu \mathrm{L} 2 \mu \mathrm{M}$ poly(dT) primer (with fluorescent label, see legend to Figure 2), $0.25 \mu \mathrm{L}$ RT reaction, $9.95 \mu \mathrm{L}$ water and 0.2 U AmpliTaq DNA Polymerase. If a fluorescent primer was not used, the reaction was labeled with either $0.2 \mu \mathrm{L}$ $(2 \mu \mathrm{Ci}){ }^{33} \mathrm{P}-\mathrm{dATP}$ at $10 \mathrm{mCi} / \mathrm{mL}$ or $0.2 \mu \mathrm{L} 100 \mathrm{nM}$ [R110] dUTP, $100 \mathrm{nM}$ [R6G]dUTP or $400 \mathrm{nM}$ [TAMRA]dUTP. PCRs using 13-mer arbitrary primers were cycled in either a GeneAmp PCR System 2400 or a GeneAmp PCR System 9600 using the following cycling parameters: denaturation for $2 \mathrm{~min}$ at $94^{\circ} \mathrm{C}$, followed by 40 cycles of $94^{\circ} \mathrm{C}$ for $15 \mathrm{~s}, 40^{\circ} \mathrm{C}$ for $2 \mathrm{~min}$ and $72^{\circ} \mathrm{C}$ for $30 \mathrm{~s}$ and a final extension for $5 \mathrm{~min}$ at $72^{\circ} \mathrm{C}$ and a $4^{\circ} \mathrm{C}$ hold.

Alternative cycling parameters for these cyclers were denaturation for $2 \mathrm{~min}$ at $94^{\circ} \mathrm{C}$ followed by 1 cycle of $94^{\circ} \mathrm{C}$ for 5 $\mathrm{s}, 40^{\circ} \mathrm{C}$ for $5 \mathrm{~min}$ and $72^{\circ} \mathrm{C}$ for $30 \mathrm{~s}$ and then 40 cycles of $94^{\circ} \mathrm{C}$ for $5 \mathrm{~s}, 45^{\circ} \mathrm{C}$ for $2 \mathrm{~min}$ and $72^{\circ} \mathrm{C}$ for $30 \mathrm{~s}$ and a final extension for 5 min at $72^{\circ} \mathrm{C}$ and a $4^{\circ} \mathrm{C}$ hold; see legend to Figure 6. For a GeneAmp PCR System 480, the cycling parameters were denaturation for $2 \mathrm{~min}$ at $94^{\circ} \mathrm{C}$, followed by 40 cycles of $94^{\circ} \mathrm{C}$ for $30 \mathrm{~s}, 40^{\circ} \mathrm{C}$ for $2 \mathrm{~min}$ and $72^{\circ} \mathrm{C}$ for $30 \mathrm{~s}$, and a final extension for $5 \mathrm{~min}$ at $72^{\circ} \mathrm{C}$ and a $4^{\circ} \mathrm{C}$ hold. PCRs that use the opa04 10-mer arbitrary primer (see legend to Figure 7) were cycled as described above for the GeneAmp PCR System 480.

\section{Marker Labeling}

The 1-kb ladder was end-labeled with either ${ }^{33} \mathrm{P}-\mathrm{dATP}$ or [R6G]-dUTP using the following protocols. For ${ }^{33} \mathrm{P}-\mathrm{dATP}$, a $25-\mu \mathrm{L}$ reaction contained approximately $1 \mu \mathrm{g} 1-\mathrm{kb}$ ladder, 50 $\mathrm{mM}$ Tris-HCl, pH 8.0, $50 \mathrm{mM} \mathrm{NaCl}, 10 \mathrm{mM} \mathrm{MgCl} 2,200 \mu \mathrm{M}$ dCTP, $200 \mu \mathrm{M}$ dGTP, $200 \mu \mathrm{M}$ dTTP, $5 \mu \mathrm{Ci}{ }^{33 P}$-dATP and 2.5

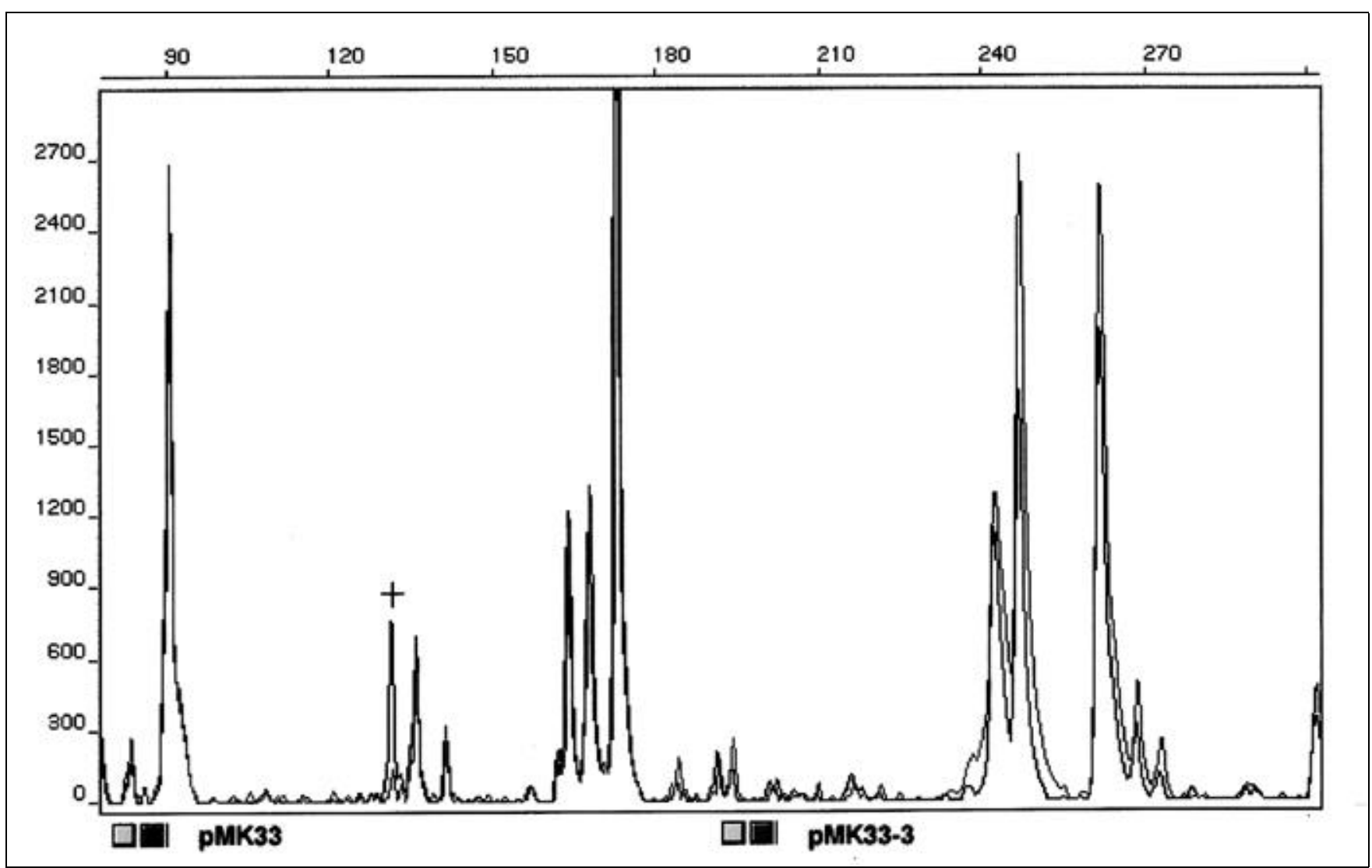

Figure 4. Electropherogram tracing of analyzed data. A portion of lanes 7 and 8 from Figure 3 (TAMRA.H-T11A and H-AP36) were analyzed with GENESCAN software. pMK33 (black line) and pMK33-3 (red line) show similar profiles except for the peak marked by a cross; this peak possibly represents a differentially expressed cDNA. The y axis is numbered in nucleotides. 
U Klenow DNA polymerase. For [R6G]dUTP, the same reaction components were used except that dATP was substituted for dTTP and [R6G]dUTP was added to a final concentration of $2 \mathrm{nM}$. Each reaction was incubated for $15 \mathrm{~min}$ at $22^{\circ} \mathrm{C}$ and then at $70^{\circ} \mathrm{C}$ for $5 \mathrm{~min}$. Water was added to bring the volume to about $100 \mu \mathrm{L}$, and the unincorporated nucleotides were removed with a spin column. About $3 \mu \mathrm{L}$ of the radiolabeled reaction or 0.5 to $1 \mu \mathrm{L}$ of the [R6G]-labeled reaction was run per lane.

\section{Gel Electrophoresis on an Automated Sequencer}

Following PCR, 0.5 $\mu \mathrm{L}$ FAM-labeled reaction, $1 \mu \mathrm{L}$ JOElabeled reaction or $2 \mu \mathrm{L}$ TAMRA-labeled reaction was mixed with $1.5 \mu \mathrm{L}$ loading dye $(0.5 \%$ blue dextran in formamide $)$ and $0.5 \mu \mathrm{L}$ GENESCAN-500 ROX size standards. On some gels, the 1-kb ladder labeled with [R6G]dUTP was included as an additional marker. The mixtures were heated to $90^{\circ} \mathrm{C}$ for 2 min and loaded onto a $24-\mathrm{cm}, 6 \%$ denaturing polyacryl-

\section{TAMRA.H-T11A + JOE.H-T11C + FAM.H-T11G}

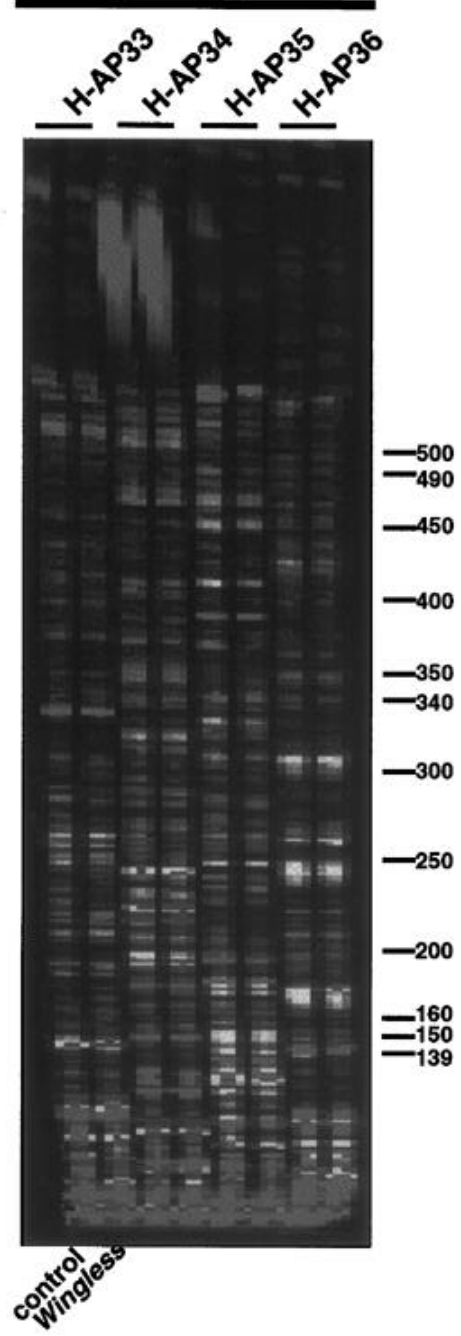

Figure 5. Multiplex of different fluorophore-labeled PCRs. Amplified cDNAs from the primer sets shown in Figure 2 were mixed and electrophoresed as described in Materials and Methods. Each color can be visualized separately using a feature in the GENESCAN software. The GENESCAN-500 ROX size standards are in red; the length (in nucleotides) of each standard is shown to the right of the gel. 
amide gel. Electrophoresis was done in $1 \times$ TBE buffer at 35 $\mathrm{W}$ constant power for $13 \mathrm{~h}$. The reactions can also be "multiplexed" by mixing the above quantities of different colored reactions, drying in a SpeedVac ${ }^{\circledR}$ (Savant Instruments, Farmingdale, NY, USA) and resuspending in loading buffer containing GENESCAN-500 ROX size standards; each fluorophore can be analyzed separately using GENESCAN analysis software.

\section{Agarose Gel Electrophoresis}

Three-millimeter-thick, 3\% NuSieve GTG agarose gels were poured according to the manufacturer's instructions. Ten microliters of the PCR were mixed with $2 \mu \mathrm{L}$ of loading dye and electrophoresed at $5 \mathrm{~V} / \mathrm{cm}$. The gel was stained with $1 \times$ SYBR Green in $1 \times \mathrm{TBE}$ for $1 \mathrm{~h}$ and visualized on a UV-light box.

\section{RESULTS AND DISCUSSION}

\section{DDRT-PCR with Fluorescent Primers}

Initial attempts to detect DDRT-PCR products synthesized with a fluorescent primer were negative. We reasoned that limiting quantities of PCR product were made and that the fluorescent signal was below the detection limit of the automated sequencer. The original DDRT-PCR protocol (7) recommends a very low (ca. $4 \mu \mathrm{M}$ ) dNTP concentration for PCR amplification. The low dNTP concentration probably limits

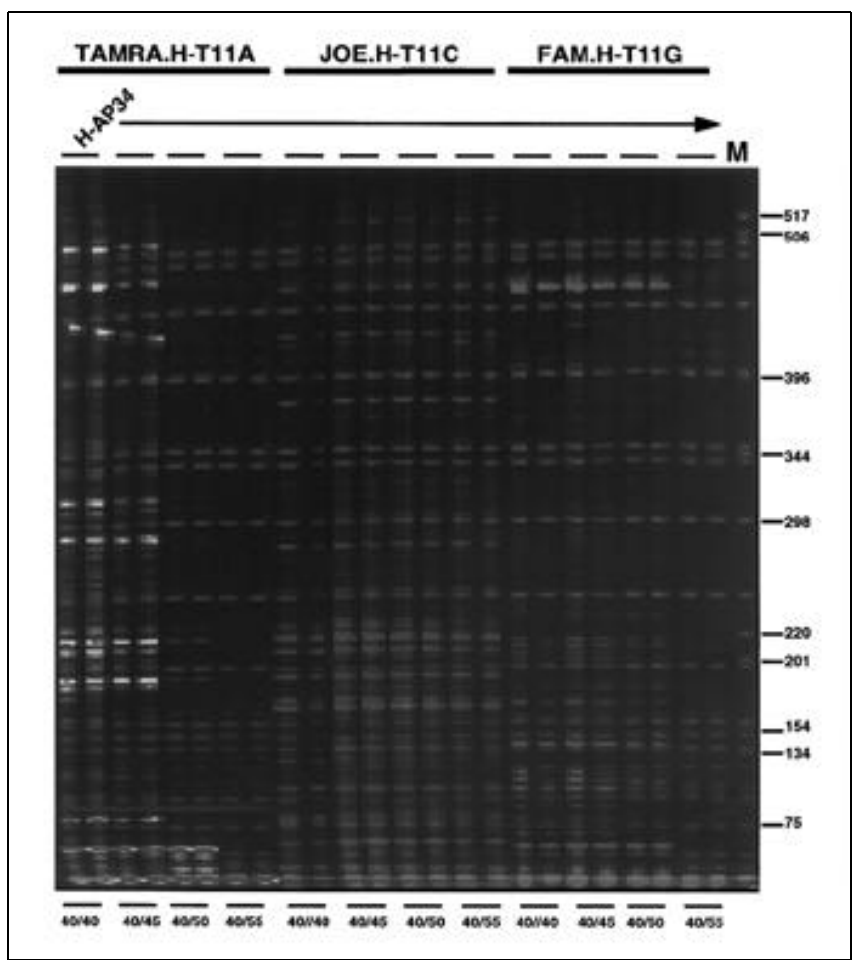

Figure 6. DDRT-PCRs done with increasing annealing temperatures. The reaction conditions are described in Materials and Methods. Briefly, one cycle with a $40^{\circ} \mathrm{C}$ anneal temperature is followed by 40 cycles with an anneal temperature ranging from $40^{\circ}$ to $55^{\circ} \mathrm{C}$. Each set of lanes compares Drosophila control (left) and Wingless (right) RNAs. The arbitrary primer for all reactions is HAP-34. The 1-kb ladder labeled with [R6G]dUTP (green) is run in the marker lane. The GENESCAN-500 ROX size standards are in red. the total mass of cDNA synthesized, even after 40 rounds of amplification. By increasing the concentration of dNTPs to $100 \mu \mathrm{M}$, we were able to detect amplification products labeled with either a fluorescent primer or with fluorescent dUTPs. Figure 3 shows a set of DDRT-PCRs using RNA from a Drosophila cell line transformed with the Wingless gene compared with RNA from the untransformed control cell line. Three different poly(dT) primers (each labeled with a different fluorophore) were used in combination with four different arbitrary primers. There are approximately $75-125$ detectable cDNAs per lane, in good agreement with the number of cDNAs routinely observed with protocols using a radiolabel. The concordance of cDNAs between the two RNA samples is excellent. Figure 4 shows an analysis of a portion of lanes seven and eight. As expected, the expression of most cDNAs is quantitatively similar in the two samples. Other combinations of poly(dT) and arbitrary primers gave similar results (data not shown). Different combinations of the TAMRA, JOE and FAM fluorophores and poly(dT) primers can be made without affecting the cDNA fingerprint (data not shown).

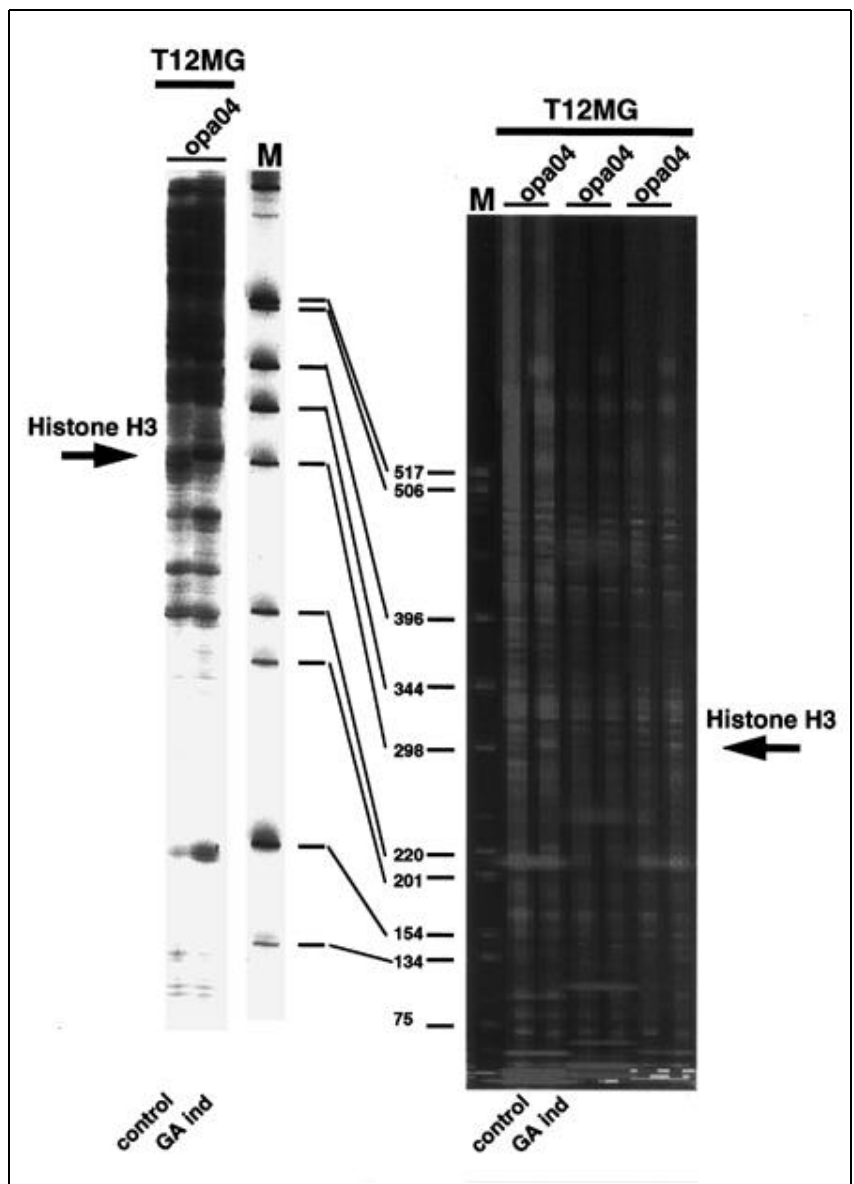

Figure 7. Radioactive and fluorescent DDRT-PCR analyses of control and GA-induced rice plants. The reaction conditions are outlined in Materials and Methods. The left panel shows band patterns obtained after DDRTPCR with ${ }^{33} \mathrm{P}-\mathrm{dATP}$ and autoradiography. The right panel shows band patterns obtained after DDRT-PCR with a fluorescent dUTP labeled with either [R110] (blue), [R6G] (green) or [TAMRA] (yellow). Control and GA-induced RNA samples are in alternating lanes. In each lane there appear diffuse bands caused by fluorescent-labeled reaction by-products; these can be removed by exclusion chromatography. The arrows point to the gel position showing the GA-induced histone H3 cDNA. In both gels, the 1-kb ladder is used for a size marker. 
If different fluorophores are used to label the poly(dT) primers, the reactions can be mixed following PCR, dried, resuspended in loading buffer and electrophoresed. Figure 5 shows the results of 'multiplexing' the 24 reactions displayed in Figure 3. By multiplexing the reactions, throughput is increased threefold. The GENESCAN software is capable of separating the signal from each fluorophore for further analysis. It should be noted that intense signals from abundant cDNAs can "bleed" into the other colors, potentially confusing the analysis. RT reactions that use a different poly $(\mathrm{dT})$ primer cannot be amplified in the same PCR. An unreadable pattern results, probably caused by the mis-priming of cDNAs with the incorrect poly(dT) primer (data not shown).

\section{PCR Optimization}

A serious limitation of DDRT-PCR is the appearance of cDNA bands that are not differentially expressed (false positives). This problem is due in part to imperfect primer hybridization at the low annealing temperature $\left(40^{\circ} \mathrm{C}\right)$ used for each cycle of PCR. DDRT-PCR reproducibility can be improved by doing the first cycle of PCR at a low annealing temperature $\left(40^{\circ} \mathrm{C}\right.$; to allow imperfect hybridization of the arbitrary primer and extension), followed by 40 cycles at an increased annealing temperature $\left(\geq 40^{\circ} \mathrm{C}\right)(16)$. To increase the specificity of primer hybridization, we tested the TAMRA. H-T11A, JOE.H-T11C and FAM.H-T11G primers and $\mathrm{H}-\mathrm{AP} 34$ in PCRs in which $40^{\circ} \mathrm{C}$ was the annealing temperature for the first cycle and $40^{\circ}, 45^{\circ}, 50^{\circ}$ or $55^{\circ} \mathrm{C}$ was used for an additional 40 cycles. The results are shown in Figure 6.

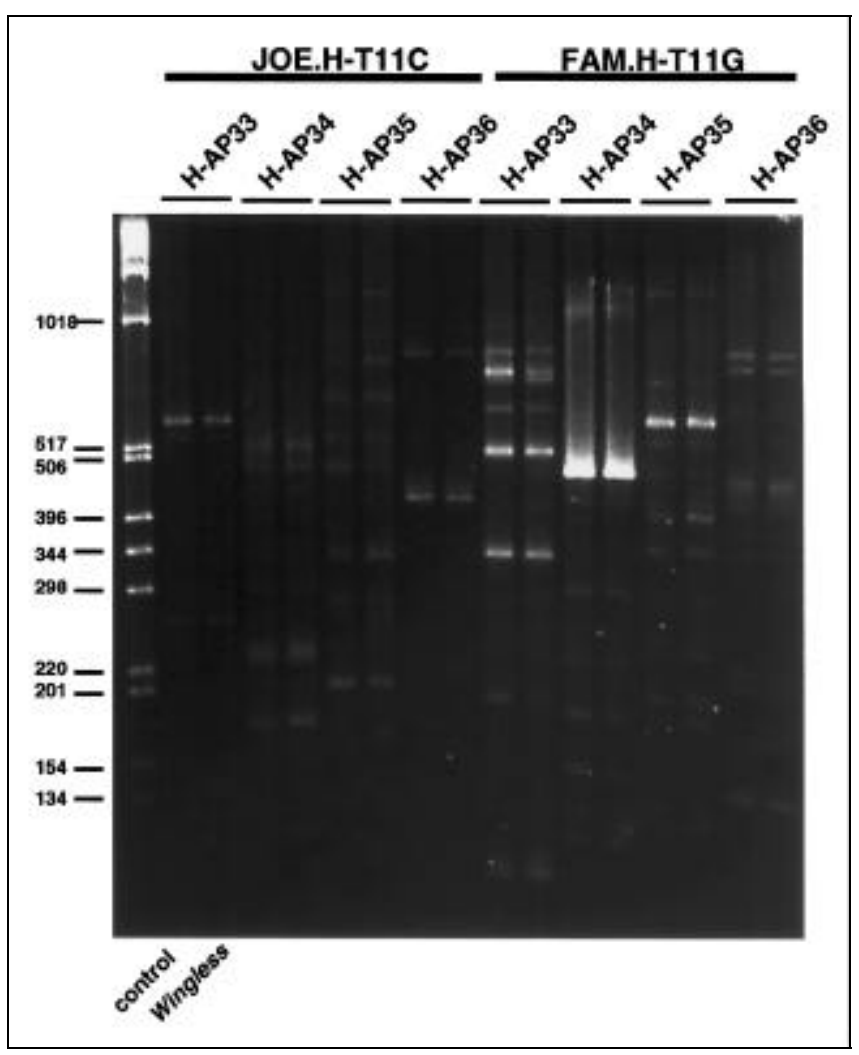

Figure 8. Agarose gel analysis of DDRT-PCR cDNA products. Amplified cDNAs from the JOE.H-T11C and FAM.H-T11G reactions shown in Figure 3 were reanalyzed by agarose gel electrophoresis as described in Materials and Methods. $10 \mu \mathrm{L}$ of each PCR were run per lane. The DNA was stained with SYBR Green and visualized by UV light. 
Each of the three poly $(\mathrm{dT})$ primers shows a different response to the increased annealing temperatures. The reactions done with JOE.H-T11C show little change even with an annealing temperature of $55^{\circ} \mathrm{C}$. The TAMRA.H-T11A reactions have little signal above $45^{\circ} \mathrm{C}$, while the FAM.HT11G reactions are little changed up to $50^{\circ} \mathrm{C}$. Although each primer responded differently, generally there is decreased synthesis as the annealing temperature is increased. This indicates either that the fluorophore decreases the melting temperature $\left(T_{m}\right)$ of the oligonucleotide and/or that the selective nucleotide is not completely anchored at the higher annealing temperatures, precluding extension. If the same cycling conditions are used for all poly(dT) primers, we recommend an annealing temperature of $\leq 45^{\circ} \mathrm{C}$.

\section{DDRT-PCR with Fluorescent dUTPs}

DDRT-PCR products can also be detected by incorporating fluorescent dUTPs instead of a labeled primer. The GENESCAN display in Figure 7 shows a DDRT-PCR comparison of RNAs from control and GA-induced rice plants; the poly(dT) primer is T12MG (7) and the arbitrary primer is opa04 (14). The DDRT-PCRs were done by incorporating dUTPs labeled with either [R110] (blue), [R6G] (green) or [TAMRA] (yellow). Note that the cDNA band pattern appears equivalent for the three dUTP derivatives. The GENESCAN display in Figure 7 appears blurry when compared with reactions done using labeled primers (cf Figure 3). The same observation was reported for radiolabeled primers vs. the direct incorporation of labeled nucleotide $(12,13)$. The blurriness likely is caused by the spurious accumulation of PCR products primed at both ends by an arbitrary primer; these products would not be detected using a labeled poly(dT) primer.

It was reported that in rice, a differentially displayed band encoding histone $\mathrm{H} 3$ was detected after induction by GA (14). In Figure 7, a differentially displayed band at approximately $300 \mathrm{nt}$ appears in the GA-induced, but not the control, lane in agreement with the earlier report.

\section{Recovery of Differentially Expressed cDNAs}

DDRT-PCR samples run on an automated sequencer pass into the buffer well after detection, precluding subsequent cDNA recovery. However, the differentially expressed cDNAs detected using GENESCAN can be recovered. For example, the rice GA-induced and control DDRT-PCRs were redone using the same RT reaction and ${ }^{33} \mathrm{P}$-dATP. The autoradiograph and GENESCAN image are compared in Figure 7. To align the equivalent bands, it is essential to run the same molecular weight markers on each gel. For this purpose, we used the 1-kb ladder end-labeled with either ${ }^{33} \mathrm{P}-\mathrm{dATP}$ or [R6G]dUTP. As shown in Figure 7, the histone H3 cDNA appears induced in the GA-treated RNA sample in both the autoradiograph and the GENESCAN image. We confirmed that the differentially expressed band was rice histone $\mathrm{H} 3$ cDNA by excising it from the radiolabeled gel and sequencing it.

Alternatively, the DDRT-PCR samples can be separated by agarose gel electrophoresis. Figure 8 shows some of the DDRT-PCRs from Figure 3 run on a 3\% NuSieve GTG agarose gel and stained with SYBR Green. Many of the abundant cDNAs are clearly visible. The desired band can be excised from the gel, purified and reamplified or sequenced. Alternatively, the DDRT-PCR samples can be run on a $10 \%$ acrylamide gel for better resolution and stained with SYBR Green (data not shown). An acrylamide gel can also be stained with silver for increased sensitivity; approximately the same band intensity is achieved when compared with radiolabeling (data not shown). cDNAs excised from silverstained gels can be reamplified (10) and used for further analysis.

\section{ACKNOWLEDGMENTS}

This paper is dedicated to the memory of Chris Marvel. The authors thank Rick Abramson, Hans Kende and Paula Mahoney for comments on the manuscript. Figure 1 was edited from a drawing by Eric Mayrand. This work was supported in part by grants from the USAMRDC (\#940544) to SC and from the NSF (IBN 9407763) to EvdK.

\section{REFERENCES}

1.Adati, N., T. Ito, C. Koga, K. Kito, Y. Sakaki and K. Shiokawa. 1995. Differential display analysis of gene expression in developing embryos of Xenopus laevis. Biochim. Biophys. Acta 1262:43-51.

2.Bauer, D., H. Muller, J. Reich, H. Riedel, V. Ahrenkiel, P. Warthoe and M. Strauss. 1993. Identification of differentially expressed mRNA species by an improved display technique (DDRT-PCR). Nucleic Acids Res. 21:4272-4280.

3.Donohue, P.J., G.F. Alberts, Y. Guo and J.A. Winkles. 1995. Identification by targeted differential display of an immediate early gene encoding a putative serine/threonine kinase. J. Biol. Chem. 270:10351-10357.

4.Hubank, M. and D.G. Schatz. 1994. Identifying differences in mRNA expression by representational difference analysis of cDNA. Nucleic Acids Res. 22:5640-5648.

5.Ito, T., K. Kito, N. Adati, Y. Mitsui, H. Hagiwara and Y. Sakaki. 1994. Fluorescent differential display: arbitrarily primed RT-PCR fingerprinting on an automated DNA sequencer. FEBS Lett. 351:231-236.

6.Liang, P., L. Averboukh, K. Keyomarsi, R. Sager and A.B. Pardee. 1992. Differential display and cloning of messenger RNAs from human breast cancer versus mammary epithelial cells. Cancer Res. 52:6966-6968.

7.Liang, P. and A.B. Pardee. 1992. Differential display of eukaryotic messenger RNA by means of the polymerase chain reaction. Science 257:967971.

8.Liang, P., W. Zhu, X. Zhang, Z. Guo, R.P. O'Connell, L. Averboukh, F. Wang and A.B. Pardee. 1994. Differential display using one-base anchored oligo-dT primers. Nucleic Acids Res. 22:5763-5764.

9.Linskens, M.H.K., J. Feng, W.H. Andrews, B.E. Enlow, S.M. Saati, L.A. Tonkin, W.D. Funk and B. Villeponteau. 1995. Cataloging altered gene expression in young and senescent cells using enhanced differential display. Nucleic Acids Res. 23:3244-3251.

10.Lohmann, J., H. Schickle and T.C. Bosch. 1995. REN display, a rapid and efficient method for nonradioactive differential display and mRNA isolation. BioTechniques 18:200-202.

11.McClelland, M., F. Mathieu-Daude and J. Welsh. 1995. RNA fingerprinting and differential display using arbitrarily primed PCR. Trends Genet. 11:242-246.

12.Tokuyama, Y. and J. Takeda. 1995. Use of ${ }^{33} \mathrm{P}$-labeled primer increases the sensitivity and specificity of mRNA differential display. BioTechniques 18:424-425.

13.Trentmann, S.M., E. van der Knaap and H. Kende. 1995. Alternatives to ${ }^{35} \mathrm{~S}$ as a label for the differential display of eukaryotic messenger RNA [letter]. Science 267:1186-1187.

14.van der Knaap, E. and H. Kende. 1995. Identification of a gibberellininduced gene in deepwater rice using differential display of mRNA. Plant Mol. Biol. 28:589-592.

15.Velculescu, V.E., L. Zhang, B. Vogelstein and K.W. Kinzler. 1995. Serial analysis of gene expression. Science 270:484-487.

16.Zhao, S., S.L. Ooi and A.B. Pardee. 1995. New primer strategy improves precision of differential display. BioTechniques 18:842-850.

Address correspondence to Kenneth R. Luehrsen, Boehringer Mannheim Diagnostics, 2380 Bisso Lane, Concord, CA 94524-4117, USA. 